\title{
Perancangan Lambung Kapal Tanpa Awak Sebagai Alat Bantu Survei Di Kepulauan Riau
}

\author{
Sapto Wiratno Satoto $\left.{ }^{1 *}\right)$ \\ ${ }^{1)}$ Politeknik Negeri Batam \\ Jl. Ahmad Yani, Tlk. Tering, Kota Batam, Kepulauan Riau 29461
}

diajukan pada :29/01/19 direvisi pada :09/03/19 diterima pada $:$ 18/03/19

\begin{abstract}
Abstrak
Kepulauan Riau merupakan kepulauan terluar Indonesia dimana posisinya dekat dengan Singapura, Malaysia serta memiliki laut yang merupakan jalur silang perkapalan internasional yang menjadikannya sebagai tempat yang strategis sekaligus berbahaya karena menyimpan kekayaan dan faktor bahaya. Letak yang strategis tersebut perlu diimbangi dengan pengamanan yang memadai yang dapat dilakukan dengan cara terbuka maupun secara diam-diam. Pengamanan terbuka diperlukan untuk melakukan penekanan secara langsung terhadap hal yang mencurigakan dan pengaman secara diam-diam diperlukan untuk guna melakukan tindakan yang senyap serta pengumpulan data dan bukti untuk mengungkap pelanggaran. Dari permasalahan tersebut, untuk tindakan pengawasan dibuatlah sebuah kapal tanpa awak sebagai salah satu solusi menyelesaikan permasalahan. Desain kapal harus mampu mengatasi hambatan yang salah satu di antaranya adalah gelombang. Penelitian ini dilakukan di sekitar pulau Batam dan pulau kecil di sekitarnya. Dari penelitian yang dilakukan didapatkan bahwa ukuran kapal yang didapatkan adalah: LOA :0,70, LWL :0,66, B 0,24, $H: 0,75, T: 0,35, C b: 0,94, C m: 1$.
\end{abstract}

Copyright (C) 2019, KAPAL, 1829-8370 (p), 2301-9069(e)

Kata Kunci : USV, Kapal Tanpa Awak, Perancangan Lambung Kapal, Survei

\section{PENDAHULAN}

Lambung kapal merupakan bagian kapal yang berguna untuk memberikan daya apung kapal[1]. Daya apung tersebut berfungsi sebagai kekuatan dalam menopang beban yang berasal dari penumpang serta isi muatan kapal. Nilai besaran daya apung akan mempengaruhi berat muatan yang akan dtanggung oleh kapal tersebut. Dalam penelitian ini penulis mencoba untuk mendcapatkan ukuran utama kapal yang sesuai dan aman yang digunaan untuk lambung kapal wisata di pulau petong. Ukuran utama tersebut nantinya akan digunakan sebagai dasar dalam perancangan lambung kapal wisata yang sesuai. Diharapkan dari penelitian ini nanti akan didapatkan ukuran tersebut sehingga sesuai dengan perencanaan.

Lambung kapal adalah bagian dari perahu atau kapal. Lambung kapal menyediakan daya apung yang mencegah kapal dari tenggelam. Rancang bangun lambung kapal merupakan hal yang penting dalam membuat kapal karena akan mempengaruhi kondisi kapal dalam hal stabilitas, kecepatan, konsumsi bahan bakar, kedalaman yang diperlukan dalam kaitannya dengan kolam pelabuhan yang akan disinggahi serta kedalaman alur pelayaran yang dilalui oleh kapal tersebut. Bentuk lambung kapal sangat berpengaruh terhadap kecepatan serta stabilitas pada kapal [1]. Adapun bentuk-bentuk lambung kapal yaitu seperti yang terlihat pada Gambar 1 .

\footnotetext{
*) Penulis Korespondensi :

Email : sapto@polibatam.ac.id
} 


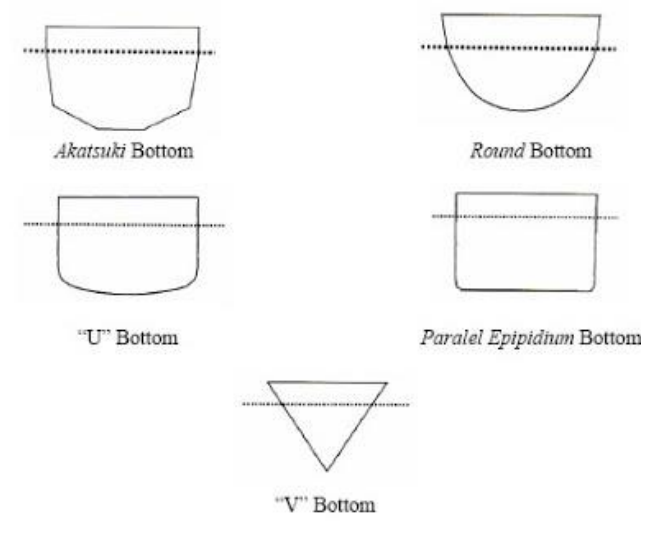

Gambar 1. Jenis Lambung Kapal [1]

Bentuk lambung kapal akan berpengaruh terhadap ukuran utama kapal. Ukuran utama kapal dapat dijelaskan sebagai berikut:

- Lwl $=$ panjang garis air

- LPP $=$ panjang seluruhnya yang terbenam

- LOS

- $\mathrm{B}$ $=$ lebar garis air

- $\mathrm{T}$ = lebar garis air

- $\mathrm{V}$ $=$ sarat rata-rata

- $\mathrm{Cb}$ $=$ Volume displasemen

- LCB = Coefisisien bentuk badan Kapal buoyancy)

- di belakang tengah kapal Koefisien dan rasio

- $\mathrm{L} / \mathrm{B} \quad=$ rasio lebar - sarat

- $\mathrm{L} / \mathrm{V}^{1 / 3} \quad=$ rasio panjang - diplasemen

- $\mathrm{LCB} / \mathrm{LPP}=$ rasio jarak titik benam di belakang tengah kapal

Ukuran utama dan koefisien di atas perlu dipertimbangakan serta perlu dilakukan perhitungan lebih lanjut agar didapatkan ukuran kapal yang memenuhi kecepatan serta bentuk lambung yang diinginkan. Parameter tersebut saling berhubungan satu sama lain sehingga ketika dilakukan perubahan ukuran di satu situ sisi, maka akan terjadi penambahan atau pengurangan di sisi yang lain. Dapat dimisalkan ketika perancang menginginkan untuk membuat kapal dengan jumlah muatan yang sama namun dengan kedalaman air yang rendah, perlu ditambahakan lebar kapal untuk mendapatkan gaya apung yang mampu untuk menggantikan ketingian dari bagian kapal yang terbenam.

Sifat karakteristik kapal tersebut dapat kita lihat dalam diagram yang disebut dengan diagram hisrostatik. Diaaram tersebut menunjukkan perubahan pola angka-angka yang terait dengan kapal setiap perubahan sarat yang terjadi pada kapal. Gambar 2 adalah kurva hidrostatik yang dimana terdapat koefisien-koefisien yang dapat dijelaskan sebagai berikut:

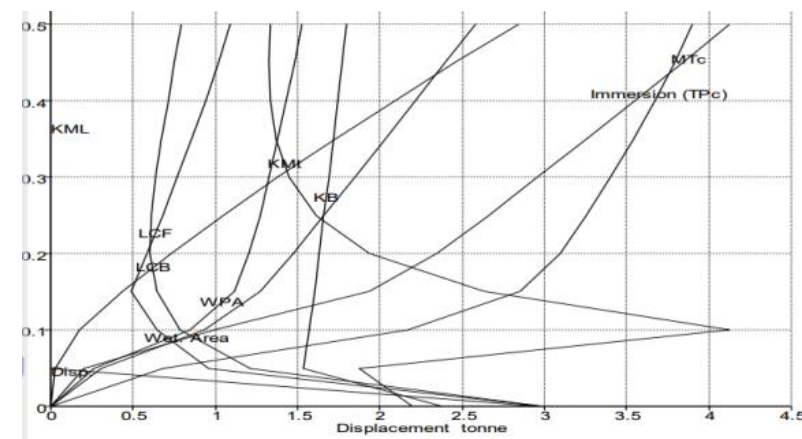

Gambar 2. Kurva Hidrostatik

MTC adalah momen yang diperlukan untuk mengadakan trim sebesar $1 \mathrm{~cm}$. Satuannya dalam Ton meter.

Volume displacement (V) menunjukkan volume badan kapal yang berada di bawah garis air dan nilainya sama dengan volume air laut yang dipindahkan pada saat kapal terbenam pada garis air tertentu.

Ton displacement $(\Delta)$ menunjukkan besarnya berat badan kapal di bawah garis air atau menggambarkan berat air yang dipindahkan oleh badan kapal yang terbenam. Semakin besar nilai ton displacement sebuah kapal maka bagian kapal yang terbenam di bawah permukaan air juga semakin tinggi.

Waterplane area (Aw) menunjukkan luas area kapal pada garis air tertentu secara horizontal-longitudinal. Besarnya nilai waterplane area tersebut tergantung dari tinggi garis air, dimana semakin tinggi garis air maka luas area kapal yang terbenam juga semakin besar.

Ton per centimeter $(\mathrm{TPc})$ menunjukkan berat yang dibutuhkan untuk merubah draft sebesar 1 $\mathrm{cm}$. Berdasarkan perhitungan diketahui bahwa semakin tinggi garis air (WL) maka nilai TPc semakin meningkat. Hal tersebut menunjukkan bahwa semakin tinggi garis air maka beban yang dibutuhkan untuk merubah draft sebesar $1 \mathrm{~cm}$ semakin besar. Oleh karena itu TPc berfungsi untuk mengetahui seberapa besar pengaruh perubahan muatan di atas kapal, baik dengan penambahan atau pengurangan muatan terhadap perubahan ketinggian draft.

Coefficient of fineness yang biasa disebut sebagai koefisien kegemukan kapal, merupakan salah satu parameter hidrostatik yang mencerminkan bentuk badan kapal[2] yang dapat dilihat dari nilai coefficient of fineness yang meliputi: coefficient of block $(\mathrm{Cb})$, coefficient of waterplane $(\mathrm{Cw})$, coefficient of prismatic $(\mathrm{Cp})$, coefficient of vertical prismatic (Cvp), dan coefficient of midship (Cm). 
$\mathrm{Cb}$ menunjukkan perbandingan antara nilai volume displacement kapal dengan volume bidang balok yang mengelilingi badan kapal. $\mathrm{Cw}$ menunjukkan besarnya luas area penampang membujur tengah.

Longitudinal centre buoyancy (LCB) menunjukkan posisi titik apung dari midship sepanjang longitudinal kapal. Nilai LCB pada kapal yang diteliti semakin menurun seiring dengan bertambahnya garis air kapal. Hal ini menunjukkan letak titik apung secara longitudinal bergerak ke arah buritan. Oleh karena itu, sebaiknya penempatan muatan sebagian besar diletakkan pada daerah midship sampai buritan.

Jarak KB menunjukkan posisi titik buoyancy dari lunas kapal secara vertikal. Semakin tinggi garis air maka jarak KB akan semakin bertambah. Hal ini dikarenakan semakin bertambahnya garis air sehingga berakibat semakin besar gaya apung yang bekerja ke atas.

Jarak BM (radius metacentre) menunjukkan jarak antara titik buoyancy terhadap titik metacentre secara vertikal. Nilainya mengalami fluktuasi karena BM merupakan parameter yang berpengaruh pada kestabilan kapal, dimana semakin jauh jarak titik B terhadap titik M maka akan berpengaruh positif terhadap kestabilan kapal.

Dalam proses pembuatan kapal tanpa awak, pernah dilakukan beberapa penelitian yang terkait dengan persenjaataan[3], deteksi sampah[4] serta untuk meakukan penyeamatan di laut[5]. Dari penelitian yang dilakukan tersebut dapat ditarik satu kesimpulan bahwa langkah tersebut ditempuh unuk mempermudah kinerja manusia bekerja dalam situasi yang sulit dan tidak terprediksi. Situasi sulit yag dimaksud disini adalah situasi dimana perkerjaan tersebut mengandung potensi bahaya yang jika dikerjakan oleh manusia akan menjadi resiko.

Kapal tanpa awak juga bisa dijadikan alat bantu bahkan senjata untuk meminimalisir bahkan menhilangkan resiko kehilangan nyawa akibat pertempuran yang terjadi. Dalam penelitian ini, salah satu nilai output yang ingin dikeluarkan oleh peneliti bahwa adanya satu model kapal tanpa awak untuk kegiatan survei di di laut khususnya di perairan yang dekat dengan perbatan luar negeri indonesi untuk mengurangi resiko adanya potensi bahaya dan keamanan ketika melakukan survey. Survey yang dilakukan disini bisa dalam bentuk survey batas laut, survey potensi bawah laut serta survey keamanan laut untuk kepentingan bangsa dan negara Indonesia.

\section{METODE}

Metodologi penelitian adalah sekumpulan peraturan, kegiatan, dan prosedur yang digunakan oleh pelaku suatu disiplin ilmu. Metodologi juga merupakan analisis teoritis mengenai suatu cara dalam melakukan penelitian. Dalam penelitian ini metode yang digunakan yaitu perbandingan namun dengan menggunakan kapal acuan sebagai sumber pembanding. Kapal acuan yang dimaksud adalah kapal dengan ukuran besar yang beroperasi pada daerah perairan terkait. Dari model kapal tersebut kemudian dibuatkan purwarupanya dalam ukuran yang diangap sesuai untuk memasukkan alat survei kapal sehingga ukurannya akan lebih dari ukuran sebenarnya.

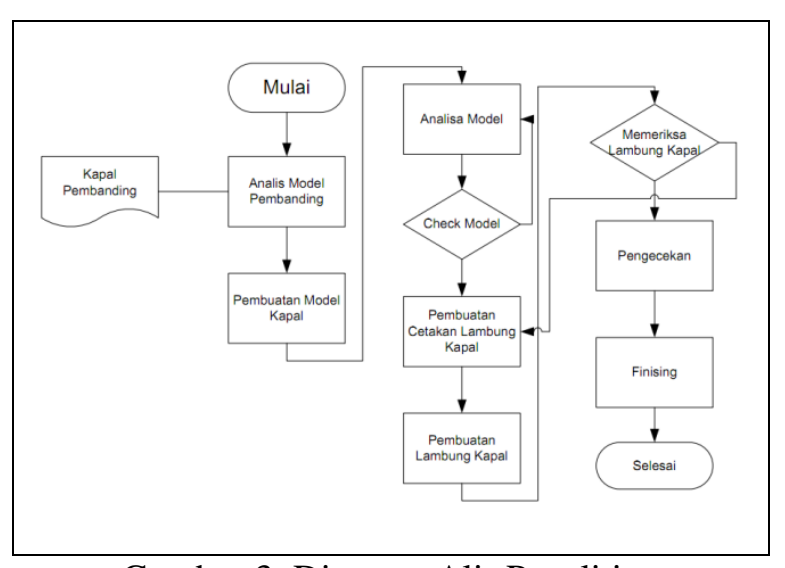

Gambar 3. Diagram Alir Penelitian

Gambar 3 adalah diagram alir penelitian. Dari diagram tersebut dapat dijelaskan bahwa proses pembuatan akan dimulai dengan membuat desain untuk kemudian dibuat purwarupa. Setelah proses pembuatan purwarupa akan dilakukan lagi redesain untuk melihat kembali apakah proses desain sudah dilakukan sesuai dengan perencanaan awal. Jika proses dan hasilnya sudah sesuai dengan perencanaan maka untuk selanjutnya proses yang dilakukan adalah proses akhir. Namun jika tidak memenuhi akan dilakukan proses redesain agar hasilnya sesuai dengan yang direncankan ketika proses desain.

\section{HASIL DAN PEMBAHASAN}

Dalam proses penelitian ini hal pertama yang dilakukan adalah melakukan suevei. Survei merupakan kegiatan yang dilakukan untuk melihat secara langsung kondisi terkait dengan penelitian. Survei dilakukan di sekitar pulau Batam dengan mengambil lokasi di pulau-pulau terluar yang bersinggungan dengan perbatasan negara asing serta pulau-pulau lain di sekitar Batam. Survei yang kami lakukan ini bertujuan untuk mengetahui kondisi gelombang dan perairan di sekitar Pulau Batam. Data hasil survei dapat dilihat pada Tabel 1. 
Tabel 1. Kondisi Gelombang Rata-Rata Pulau Batam

\begin{tabular}{|c|c|c|c|c|}
\hline No & Lokasi & Waktu & $\begin{array}{c}\text { Tinggi } \\
\text { Gelombang }\end{array}$ & Rata-rata \\
\hline \multirow[t]{3}{*}{1} & Jembatan & 07.00 & $150.00 \mathrm{~mm}$ & \\
\hline & 1 Barelang & 12.00 & $130.00 \mathrm{~mm}$ & $150.00 \mathrm{~mm}$ \\
\hline & & 15.00 & $170.00 \mathrm{~mm}$ & \\
\hline \multirow[t]{3}{*}{2} & Jembatan & 07.00 & $160.00 \mathrm{~mm}$ & \\
\hline & 3 Barelag & 12.00 & $120.00 \mathrm{~mm}$ & $153.33 \mathrm{~mm}$ \\
\hline & & 15.00 & $180.00 \mathrm{~mm}$ & \\
\hline \multirow[t]{3}{*}{3} & Sembulang & 07.00 & 17.00 & \\
\hline & & 12.00 & $170.00 \mathrm{~mm}$ & $112.33 \mathrm{~mm}$ \\
\hline & & 15.00 & $150.00 \mathrm{~mm}$ & \\
\hline \multirow[t]{3}{*}{4} & Belakang & 07.00 & $500.00 \mathrm{~mm}$ & \\
\hline & Padang & 12.00 & $600.00 \mathrm{~mm}$ & $516.67 \mathrm{~mm}$ \\
\hline & & 15.00 & $450.00 \mathrm{~mm}$ & \\
\hline \multirow[t]{3}{*}{5} & Selat & 07.00 & $550.00 \mathrm{~mm}$ & \\
\hline & Singapura & 12.00 & $600.00 \mathrm{~mm}$ & $550.00 \mathrm{~mm}$ \\
\hline & & 15.00 & $500.00 \mathrm{~mm}$ & \\
\hline
\end{tabular}

Dari data tersebut didapatkan data bahwa tinggi gelombang tertinggi adalah 550 dengan lokasi di sekitar Selat Singapura dan Kondisi gelombang terendah didapatkan di sekitar pulau Barelang. Dari hasil survei, kondisi geografis mempengaruhi tinggi gelombang yang terjadi, kondisi geografis di sekitar barelang dimana pulau-pulau tersebut dikelilingi oleh pulau-pulau menyebabkan tinggi gelombang tidak terlalu tinggi namun arus laut yang ditimbulkan oleh keberadaan pulau tersebut cukup kuat.

Data gelombang tersebut diperlukan sebagai data tambahan untuk menghitung dan mensimulasikan kondisi perairan sehingga dapat diketahui pengaruh lingkungan terhadap kapal. Kondisi perarian merupakan faktor yang penting dalam proses desain kapal karena lingkungan tersebut berpengaruh terhadap kondisi gerakan kapal. Langkah berikutnya dalam proses desain ini adalah dengan cara mentukan ukuran kapal yang akan digunakan sebagai kapal pembanding (Gambar 4).

Fungsi kapal pembanding dalam proses desain kapal adalah sebagai acuan dalam proses desain sehingga ketika membuatnya tidak diperlukan banyak perubahan. Di dalam bidang industri istilah ini disebut dengan sister. Disebut sister dikarenakan kapal yang akan dibuat memiliki ukuran utama yang tidak jauh beda antara kapal yang satu dengan yang lain.

Dasar penggambaran rencana garis[6] tersebut menggunakan kapal Basarnas dikarenakan kapal tersebut dianggap lebih stabill sebab menggunakan dua lambung kapal. Kapal tersebut saat ini telah beroperasi dan digunakan oeh basarnas dalam berbagai misi penyelamat. Misi tersebut banyak berhasil sebab kapal basarnya didukung dengan perlatan yang canggih serta didukung dengan adanya bentuk lambung yang cukup mumpuni untuk melakukan proses penyelamatan.

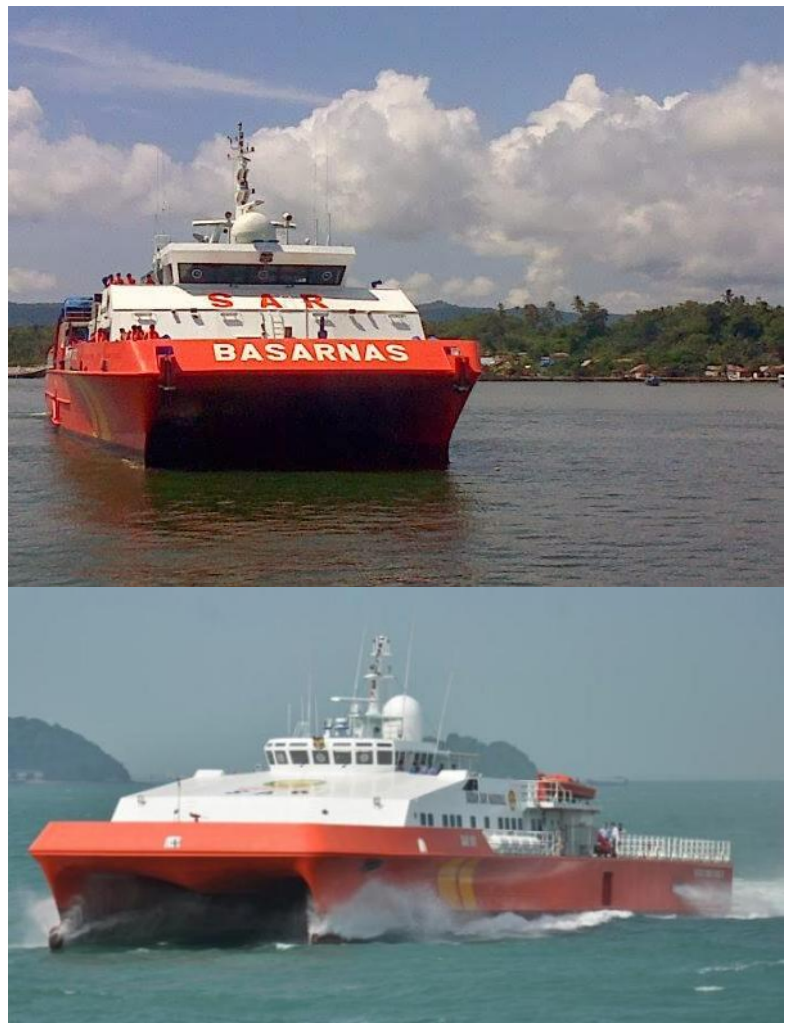

Gambar 4. Bentuk Lambung Kapal Basarnas

Istilah dua lambung di dalam desain kapal disebut dengan katamaran. Dari bentuk yang sudah jadi, dapat dilihat bahwa dengan tipe katamaran tersebut peralatan yang dapat dibawa oleh kapal lebih banyak serta pada saat operasional kondisi karakteristiknya lebih unggul dalam hal stabilitas [7] dibandingkan dengan kapal yang menggunakan satu lambung. Setelah didapatkan bentuk gambar lambung, langkah berikutnya adalah dengan melakukan proses penggambara ulang kapal. Proses penggambaran dilakukan dengan cara melihat kapal asli untuk kemudian dilakukan penggambaran di dalam perangkat lunak [8].

Terdapat beberapa data utama yang cukup penting yang perlu didapatkan di awal antara lain data ukuran utama kapal. Data ukuran utama kapal yang kami dapat antara lain;

$\begin{array}{ll}\text { LOA } & : 59,00 \text { meter } \\ \text { LWL } & : 55.60 \text { meter } \\ \text { B } & : 16,00 \text { meter } \\ \text { D } & : 4,50 \text { meter } \\ \text { T } & : 1,50 \text { meter }\end{array}$




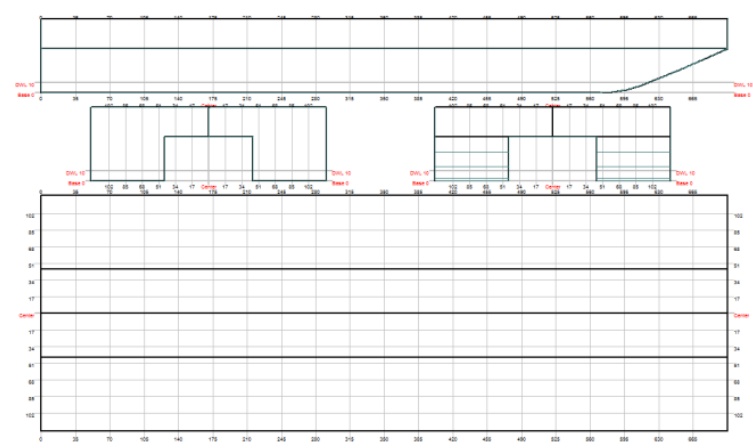

Gambar 5. Rencana Garis

Data ukuran tersebut dipadukan dengan gambar yang kapal yang diperoleh, kemudian akan dihasilkan rencana garis dari desain kapal tanpa awak. Dalam hal ini perlu dilakukan penskalaan ulang agar didapatkan ukuran kapal yang lebih kecil dari aslinya. Rencana garis menunjukkan potongan memanjang, melintang, serta tampak atas dari badan kapal. Rencana garis digunakan untuk melihat bentuk bodi kapal secara 3 dimensi namun dalam gambar 2 dimensi. Dari rencana garis ini dapat direncanakan bentuk potongan plat yang akan digunakan dalam membentuk bodi kapal. Pembuatan kapal ini digunakan dengan software Delftship yaitu sebuah software untuk membuat surface bodi kapal. Hasil Rencana Garis terdapat pada Gambar 5.

Dari rencana garis tersebut dapat diperoleh gambaran mengenai potongan kapal baik secara melintang, memanjang, tampak atas kapal, maupun tampak samping kapal dan beberapa pembagian garis. Gambaran tersebut merupakan representasi dari kapal asli sehingga dengan gambar tersebut, para pekerja terkait dengan pembangunan serta reparasi maupun desain kapal dapat mengetahui bentuk kapal dalam 2 dimensi. Dari rencana garis tersebut kita juga bisa elakukan perhitungan terkait dengan kondisi karakteristik kapal. Kondisi karakteristik ini dapta dilihat dari hungan antara satu garis dedngan garis lainnya yang terdapat dalam gambar renana garis.

Proses selanjutnya setelah dibuat rencana garis sebuah kapal adalah dengan mencari karakteristik kapal melalui kurva hidrostatik. Bentuk dan aplikasi dari kurva hidrostatik dapat dilihat pada Gambar 6.

Gambar 6 merupakan Grafik Hidrostatik yang menunjunkkan kondisi lambung kapal dalam beberapa kondisi garis air atau sarat (draft)[9]. Dari grafik hidrostatik tersebut dapat dijelaskan bahwa kenaikan dari grafik menunjukkan peningkatan yang konstan sehingga dapat dietahui bahwa bentuk lambung kapal mengalami perubahan dengan bentuk yang konstan. Dalam ketinggian sarat tertentu terlihat terdapat patahan grafik dimana dalam patahan tersebut menjelaskan adanya perubahan pada bentuk lambung kapal. Bentuk dari grafik tersebut juga menunjukkan bahwa perubahan lambung berbentuk linear yan berarti bodi kapal memiliki pola peruhan lambung yang teratur.

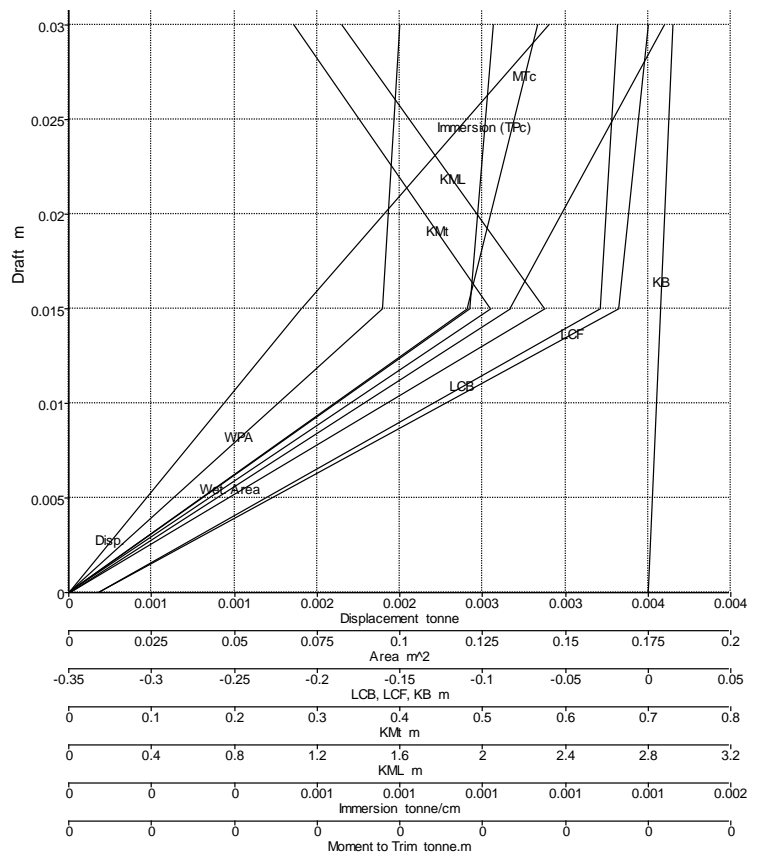

Gambar 6. Grafik Hidrostatik

Pembahasan dari kurva hidrostatik pada Gambar 6 dapat dijelaskan sebagia berikut:

- MTC (Moment Trim per Centimetre) pada kapal menunjukkan perubahan yang cukup besar samapai pada draft $15 \mathrm{~mm}$. Hal ini berarti bahwa sampai pada nilai sarat tersebut, moment yang dibutuhkan oleh kapal cukup besar dilihat dari rentang nilai yang berubah cukup curam.

- Volume displacement (V) pada kapal tapa awak menunjukkan perubahan yang drasti sampai pada draft $15 \mathrm{~mm}$. Bentuk kura yang menunjukkan perubahan yang curam dapat diartikan bahwa perubahan yang terjadi pada bentuk kapal cukup besar sehingga bisa di analogikan bahwa bentuk kapal pada daerah itu adalah meruncing

- Waterplane area (Aw) pada kurva tersebut berbentuk miring, kemudian mengarah ke tegak. Dari sini bisa diketahui bahwa luasan area ini pada awalnya bertambah untuk kemudian semakin lama semakin tetap. Sehingga bisa diketahui bahwa semakin ke atas penambahan luas semakin sama sehingga bentuk kapal semakin ke atas semakin membentuk pola persegi

- Ton per centimeter (TPc) pada grafik memiliki kecenderungan yang hampir sama dengan water plan area Kemiripan ini bisa 
disebabkan karena dua kurva tersebut saling berubungan antara satu dengan yang lain. Bisa dianalogikan bahwa semakin luas area, maka semakin besar pula beban yang dibutuhkan untuk menenggelamkan kapal sebanyak $1 \mathrm{~cm}$.

- $\mathrm{Cb}$ menunjukkan perbandingan antara nilai volume displacement kapal dengan volume bidang balok yang mengelilingi badan kapal. $\mathrm{Cw}$ menunjukkan besarnya luas area penampang membujur tengah

- Longitudinal centre buoyancy (LCB) menunjukkan posisi titik apung dari midship sepanjang longitudinal kapal. Pada kapal tersebut, titik apung nya semakin lama semakin menunjukkan angka positif. Ini berati pada kondisi sarat 0 kapal trim ke belakang. Namun seiring dengan penambahan luas area yang terendam air, kapal mulai rata (even keel).

- Jarak KB menunjukkan penambahan yang tidak signifikan namun menunjukan perubahan yang linier. Ini berarti perubahan tersebut ada di setiap drftnya sampai bagian maksimal.

- KML (Keel Metacentre Longitudinal) akan menalami fluktuasi dan pada titik tertentu nilainya akan berbalik arah. Hal ini dikarenkan pada kondisi tertu terdapat perubahan yang terkait dengan stabilitas kapal.

Setelah diketahui karakteristik kapal secara umum, kemudian dilakukan proses desain bodi secara detai untuk mengetahui bodi bentuk bodi kapal secara detail. Adapun proses pembuatan dari bodi kapal tersebut menggunakan aplikasi perangkat lunak untuk mempermudah proses penggambaran. Dari aplikasi perangkat lunak tersebut nantinya dapat dilakukan analisa untuk melanjutkan proses dan langkah berikutnya.

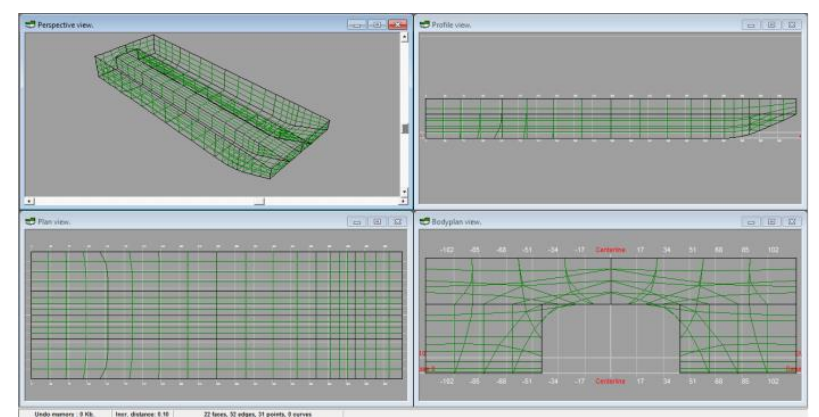

Gambar 7. Model 3 Dimensi Purwarupa

Gambar 7 adalah model 3 dimensi purwarupa, dimana model kapal yang telah dibuat selanjutnya digunakan sebagai desain yang akan dianalisa. Analisa yang dilakukan meliputi analisa untuk mengetahui karakteristik kapal dan kebutuhan daya pendorong kapal dimana dilihat dari sisi hambatan kapal. Perhitungan tersebut digunakan untuk menentukan beban yang bisa diangkut oleh kapal serta mesin dan pendorongnya. Setelah dilakukan analisa didapatkan data utama sebagai berikut:

$\begin{array}{ll}\text { LOA } & : 0,70 \\ \text { LWL } & : 0,66 \\ \mathrm{~B} & : 0,24 \\ \mathrm{H} & : 0,75 \\ \mathrm{~T} & : 0,35 \\ \mathrm{Cb} & : 0,94 \\ \mathrm{Cm} & : 1\end{array}$

Dari data tersebut bisa dilihat bahwa bentuk kapal hampir persegi (Cb: 0,94) sehingga kapal mendekati bentuk kotak. Salah satu keuntungan yang diperoleh dari bentuk yang persegi ini adalah terdapat area yang cukup luas di atas kapal sebagai lokasi atau tempat untuk meletakkan alat dan perlenkapan yang dibutuhkan oleh kapal tapa awak untuk melakukan survey serta lengkap dengan alat kendalinya[10].

Tabel 2. Data Kecepatan dan Hambatan Kapal

\begin{tabular}{rrrccc}
\hline No & $\begin{array}{c}\text { Speed } \\
(\mathrm{kts})\end{array}$ & $\begin{array}{c}\text { Holtrop } \\
\text { Resist } \\
(\mathrm{kN})\end{array}$ & $\begin{array}{c}\text { Holtrop } \\
\text { Power } \\
(\mathrm{kW})\end{array}$ & $\begin{array}{c}\text { Slender } \\
\text { body } \\
\text { resist } \\
(\mathrm{kN})\end{array}$ & $\begin{array}{c}\text { Slender } \\
\text { body } \\
\text { power } \\
(\mathrm{kN})\end{array}$ \\
\hline 1 & 0 & & & & \\
2 & 0.25 & & & & \\
3 & 0.5 & & & & \\
4 & 0.75 & & & & \\
5 & 1 & & & & \\
6 & 1.25 & & & & \\
7 & 1.5 & & & & \\
8 & 1.75 & & & & \\
9 & 2 & & & & 0.01 \\
10 & 2.25 & & & & 0.01 \\
11 & 2.5 & & & & 0.01 \\
12 & 2.75 & & & & 0.01 \\
13 & 3 & 0.01 & 0.01 & & 0.01 \\
14 & 3.25 & 0.01 & 0.01 & 0.01 & 0.01 \\
15 & 3.5 & 0.01 & 0.01 & 0.01 & 0.01 \\
16 & 3.75 & 0.01 & 0.01 & 0.01 & 0.02 \\
17 & 4 & 0.01 & 0.01 & 0.01 & 0.02 \\
18 & 4.25 & 0.01 & 0.01 & 0.01 & 0.02 \\
19 & 4.5 & 0.01 & 0.01 & 0.01 & 0.02 \\
20 & 4.75 & 0.01 & 0.01 & 0.01 & 0.03 \\
21 & 5 & 0.01 & 0.01 & 0.01 & 0.03 \\
\hline & $* 1 \mathrm{knot}: 1,852 \mathrm{~km} / \mathrm{jam}: 0,51 \mathrm{~m} / \mathrm{s}$ & \\
& & & & &
\end{tabular}

Dari Tabel 2, terlihat nilai angka yang nilainya bertambah seiring dengan perubahan nilai 
angka pada kecepatan kapal. Perubahan nilai angka pada kecepatan kemudian diikuti dengan perubahan angka yang terdapat pada nilai hambatan dan tenaga yang diperlukan oleh kapal. Dari perubahan angka yang terjadi tersebut dapat disimpulkan bahwa semakin tinggi kecepatan kapal maka hambatan yang terjadi akan semakin tinggi. Kenaikan tersebut akan sebanding pula dengan kebutuhan tenaga yang diperlukan oleh kapal. Pada beberapa titik tertentu kenaikan tenaga stabil dan tidak terjadi perbedaan kenaikan yang signifikan hal ini terjadi karena bentuk lambung kapal yang bentuknya tidak mengalami perubahan yang memiliki pola linier.

\section{KESIMPULAN}

Kesimpulan yang dapat diambil dari penelitian ini antara lain : 1) Data gelombang tertinggi yang kami dapatkan berada di Selat Singapura $(550 \mathrm{~mm})$ dan gelombang terendah berada di sekitar Pulau Barelang (+/- 150mm). 2) Arus laut terbesar berada di sekitar pulau Barelang. 3) Dari rencana garis yang dihasilkan menunjukkan ruangan deck memiliki area yang cukup luas untuk diletakkan alat keperluan survei 4) Kapal yang didesain dengan draft yang rendah sehingga memberikan keuntungan yaitu masih bisa dilengkapi dengan alat penunjang survei kelautan yang antara lain: alat kendali serta perekam data. 5) Hambatan kapal ketika dilihat dari analisa yang dilakukan kecil sehingga tenaga yang dibutuhkan untuk mendorong tidak besar (daya mesin kecil) namun hal ini perlu diperhatian pula dengan kebutuhan kecepatan kapal yang akan direncanakan

Untuk ke depannya agar penelitian ini lebih baik lagi perlu adanya penelitian untuk menentukan penggerak dan sistem kontrol kapal agar bisa digunakan secara maksimal serta perlu dibuatkan bangunan atas kapal untuk melindungi peralatan survey dan control yang digunakan.

\section{UCAPAN TERIMA KASIH}

Ucapan terimakasih diucapkan kepada Allah Yaang Maha Esa atas anugerahnya rangkaian tulisan ini dapat terselesaikan serta kepda Politeknik Negeri Batam yang telah memberikan kesempatan yang sangat besar bagi penulis untuk melakukan penelitian serta penulian karya penelitian ini.

\section{DAFTAR PUSTAKA}

[1] H. Schneekluth and V. Bertram, Ship design for efficiency and economy, vol.
218. Butterworth-Heinemann Oxford, 1998.

[2] E. V Lewis, "Principles of Naval Architecture vol III: Motions in Waves and Controllability," Soc. Nav. Archit. Mar. Eng. Jersey City, New Jersey, 1989.

[3] B. Siswandi, H. A. Santoso, and T. B. Musriyadi, "Perencanaan Unmanned Surface Vehicle (USV) Ukuran 3 Meter Tipe Serbu Cepat," J. Tek. ITS, vol. 1, no. 1, pp. G224--G229, 2012.

[4] J. Vasilj, I. Stančić, T. Grujić, and J. Musić, "Design, Development and Testing of the Modular Unmanned Surface Vehicle Platform for Marine Waste Detection," $J$. Multimed. Inf. Syst., vol. 4, no. 4, p. 195, 2017.

[5] U. S. Navy, "The navy unmanned surface vehicle (USV) master plan," Dep. Navy, Washingt. DC, Tech. Dir., 2007.

[6] K.-Y. Lee and S.-U. Lee, "An agent-based approach to preliminary ship design," $J$. Mar. Sci. Technol., vol. 5, no. 2, pp. 78 $88,2000$.

[7] D. Faturachman, M. Muslim, and A. Sudrajad, "Analisis keselamatan transportasi penyeberangan laut dan antisipasi terhadap kecelakaan kapal di Merak-Bakauheni," FLYWHEEL J. Tek. Mesin Untirta, vol. 2, no. 1, 2015.

[8] C. Kuo and K. J. MacCallum, "Computer aided applications in ship technology," Comput. Ind., vol. 5, no. 3, pp. 211-219, 1984.

[9] E. Kreuzer and W. Sichermann, "On unpredictable ship rolling in irregular seas," Nonlinear Dyn., vol. 47, no. 1-3, pp. 105-113, 2007.

[10] N. Abdurrahman, S. W. Satoto, and H. Radesha, "Kajian Pemodelan Kemudi Kapal Pengawas Tanpa Awak," $J$. Integrasi, vol. 7, no. 2, pp. 136-142, 2015. 